\title{
監視カメラ画像の可逆的プライバシー保護技法
}

\section{Reversible Privacy Protection Technique for Surveillance Camera Images}

\author{
山 本 恭 徳 $^{\dagger}$, \\ 姜錫 ${ }^{\dagger}$, 正会員 坂 本雄 北 \\ 島 浦 紳 吾†,
}

Yasunori Yamamoto ${ }^{\dagger}$, Xuefei $\mathrm{Li}^{\dagger}$, Shingo Shimaura ${ }^{\dagger}$, Seok Kang ${ }^{\dagger}$ and Yuji Sakamoto ${ }^{\dagger}$

\begin{abstract}
あらまし 近年, 監視カメラ映像におけるプライバシー侵害の問題が注目されている.これまでの可逆的プライバシー保護手法で は記録画像の流出による第三者からのプライバシー侵害行為を防ぐことができるが，監視者が確認する記録画像にはプライバシー保 護処理が施されていないため, 悪意ある監視者によるプライバシー侵害行為を防ぐことができない. 監視者が確認する記録画像に対 するプライバシー保護手法として, 目標画質より算出された二乗誤差を基準としたスクランブル処理とヒストグラム操作による復元 に関わる情報の埋め込み処理を組み合わせた手法がある，そこで本稿ではその手法に改良を加え，処理時間を大幅に短縮し，実用に 耐えうる技法を実現した。また，改良した手法において，スクランブル強度制御実験，プライバシー保護レベル評価実験および動作 の検出実験, さらに単位画像あたりの処理時間測定によるリアルタイム性評価実験を行い, その有効性を確認した.
\end{abstract}

キーワード : 可逆的プライバシー保護手法, 半開示スクランブル, データハイディング

\section{1. ま え がき}

近年，監視カメラは公共空間だけではなく，一般住宅な どの私的空間等にも設置し，利用されている.これらの監視 カメラの多くが防犯カメラとして活用され，事件が発生し た際には記録された映像を犯罪捜査に利用する場合がある.

しかし，不特定多数の人物が無差別に撮影・記録される ことから，悪意ある人物の行為により記録画像が流出した 際, 画像中の人物のプライバシーが侵害される恐れがある. そこで, 監視カメラ画像におけるプライバシー保護を目的 とした研究が注目されている [1]. 監視カメラ画像を対象と したプライバシー保護技法は，犯罪捜査等への活用を考慮 した場合，可逆的技法が望ましい。また，監視カメラ画像 は記録の際に圧縮処理が行われるため, 圧縮処理過程に含 まれる可逆的なプライバシー保護技法 [2-5] に注目する.

例えば $\mathrm{Li} ら$ 手法 [2] は, 離散ウェーブレット変換 (DWT: Discrete Wavelet Transform) を利用した可逆的 技法である. DWT 処理により対象となる人物を含む矩形 領域を低周波成分領域 (スケーリング係数) と高周波成分領 域に分割し，低周波成分領域を元の領域大に拡大すること によりプライバシー保護処理が施されていた。 また本多ら の手法 [3] は, DCT 係数值に対する擬似乱数との排他的 論理和によるスクランブル処理を用いた可逆的技法である. ジグザグスキャン順での処理範囲と擬似乱数のビット長の

2015 年 12 月 18 日受付, 2016 年 10 月 12 日再受付， 2017 年 1 月 19 日採録 $\dagger$ 北海道大学大学院 情報科学研究科

（祇 060-0814 北海道札幌市北区北 14 条西 9 丁目，TEL 011-706-6503）
パラメータを与えることによりスクランブル処理の保護レ ベルを定性的に制御することができた。

これらの可逆的なプライバシー保護技法では，監視者は 元の画像もしくは復元された画像を見て監視を行うため, 悪意ある監視者が保護処理の施されていない画像を別デバ イスにより撮影・記録し流出させた場合，画像中に映り込 む人物のプライバシーを保護することができない。対策と しては監視者が見る画像の段階でプライバシー保護処理が 施されていることが望ましい。しかし提案されてきた手法 の保護レベルの制御には設定者の経験的な考察が必要であ り，「監視を行うことのできる保護レベル」に容易に設定す ることはできない。 そこで，プライバシー保護画像から監 視を行うことが可能なスクランブル処理として, 定量的強 度制御可能な半開示スクランブル技法 $[6]$ に注目する.この 手法は客観的画質評価指標を用いて，設定者が設定した目 標画質より算出された目標二乗誤差を基準としスクランブ ル強度制御を行う。この半開示スクランブル技法を保護処 理として用いて定量的な保護レベル制御を可能とする。ま た，プライバシー保護処理を人物形状に沿って行うことで, 監視可能なプライバシー保護画像を得ることができる．復 元に必要な情報は画像の各 $8 \times 8$ ブロックの量子化後 DCT (以後 $\mathrm{qDCT}$ と表記) 係数に対して埋め込み処理を行う. ス クランブル処理と埋め込み処理は各ブロックを二つの領域 に分割し，それぞれの領域で行う。この領域分割を複数の JPEG 画像から算出された特徵に従い自動的に行い, 保護 処理後のファイルサイズ増加抑制を図る.しかし，[6]では, プライバシー保護処理を人物形状に沿って行うための人体 


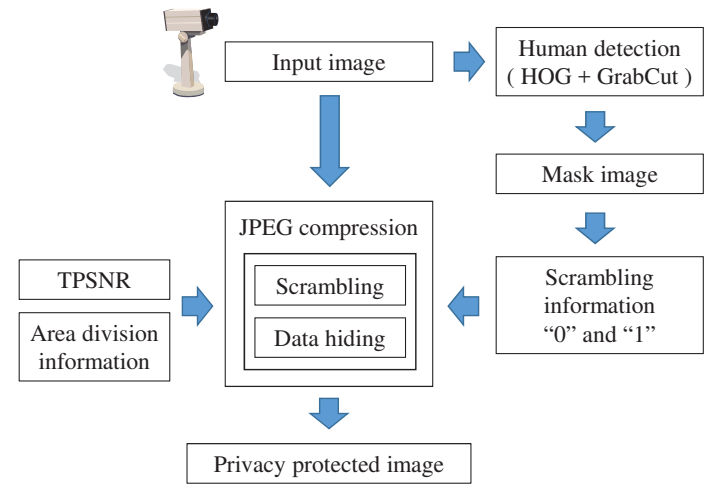

図 1 従来手法の概要図

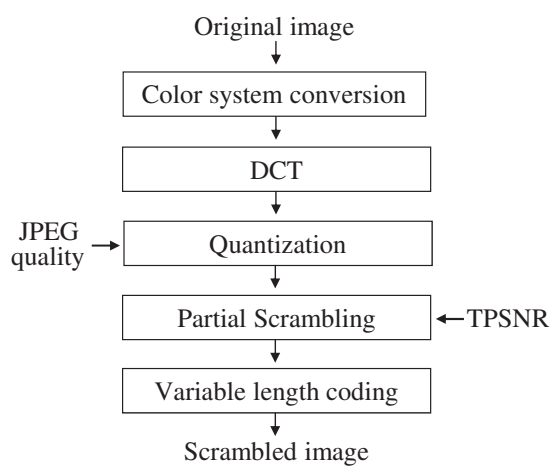

図 2 画像半開示スクランブル処理手順
検出処理を行うが，その処理が複雑であり，膨大な処理時 間がかかってしまい, リアルタイム処理が非常に困難であっ た.また，[6] では主観評価実験を行わなかったため, 手法 の有用性の確認が不充分であったと考えられる.

本論文では，目標画質より算出された二乗誤差を基準と したスクランブル処理とヒストグラムペアを用いた復元に 関わる情報の埋め込み処理を組み合わせ，定量的スクラン ブル強度制御を可能とした可逆的プライバシー保護技法を 提案する。この技法を画像内の人物領域のみに施すことで 監視者が「映り込む人物が誰であるかは分からないが何を しているか確認できる」プライバシー保護画像の生成が容 易になると考えられる. 提案手法では, 人体検出処理とし て背景差分を使用し, 従来手法より処理時間の大幅な短縮 を図る，スクランブル強度制御実験および [6] では行わな かった主観評価実験を行い, 保護レベル (スクランブル強 度) や生成したプライバシー保護画像の主観的な認識率, 劣 化度評価から提案手法の有用性を確認した。 さらに, 処理 時間とファイルサイズ増加率の評価実験を行い, 本手法は 実用に耐えうることを確認した。

\section{2. 従来手法}

本章では従来手法として，半開示スクランブル技法 [6] が組み合わせた二つの技法について説明する，従来手法の 概要図を図 1 に示す.

\section{1 半開示スクランブル技法}

二乗誤差を基準としたスクランブル強度制御 [7] の原理に ついて述べる.この手法は客観的画質評価指標である PSNR に基づいた処理である。ここで設定者が所望する目標画質 を Target PSNR(以後 TPSNR と表記) とする. TPSNR から 1 ブロック $(8 \times 8)$ あたりの DCT 係数に生じさせる べき二乗誤差 $N^{2}$ は以下の式 (1) で表される.

$$
N^{2}=\frac{64 \times 255^{2}}{10^{\mathrm{TPSNR} / 10}}
$$

二乗誤差に基づく半開示スクランブル技法は，設定された TPSNR から算出された $N^{2}$ を基準とし，各ブロック内の DCT 係数值を操作する. なお, TPSNR 值はデスクラン ブル処理に必要な復号鍵である. 半開示スクランブル処理
はJPEG 圧縮過程で行われる. 画像半開示スクランブル処 理手順は図 2 で表される. 各成分の DCT ・ 量子化処理を 終えた後, スクランブル処理に入る. 対象となる係数は $\mathrm{Y}$ 成分 $\mathrm{qDCT}$ 係数の $\mathrm{AC}$ 成分である. 入力パラメータから式 (1) により $N^{2}$ を算出する，そして各ブロックごとに $\mathrm{AC}$ 成 分に対し係数操作処理を施す. 係数操作処理は可逆的な処 理とし, 例として係数増減処理 [7] や処理後のファイルサ イズ増加を抑制できる符号反転処理 [4] などが考えられる. ブロック内で発生させた二乗誤差 $E^{2}$ が目標二乗誤差であ る $N^{2}$ を超えるか, スクランブル領域内のすべての処理を 終えたとき, 次のブロックへ処理を進める. 二乗誤差の不 足分は次のブロックへ持ち越し処理を行う。全対象ブロッ クでのスクランブル処理を終えた後, 可変長符号化処理を 行う. AC 成分は各ブロックにおいてジグザグスキャン順 で非零係数とその係数に先行する零ランレングスが同時に 符号化される。符号化にはハフマン符号が用いられる．以 上の手順を踏み, スクランブル処理が施された JPEG 画像 が出力される.

デスクランブル処理は復号鍵であるスクランブル処理時 に使用した TPSNR 值を用いて逆手順を踏む. 可変長復号 化処理の後, TPSNR 值から算出された $N^{2}$ に従いスクラ ンブル時と同様の係数操作処理を行う. そして逆量子化・ IDCT 処理・表色系変換を行い復号画像を得る.

\section{2 可逆的データハイディング技法}

JPEG 圧縮過程での処理かつ元画像を完全に復元する可 逆的なデータハイディング技法として Xuan らの手法に注 目する [9]. Xuan らの手法は, DCT 係数值のヒストグラ ム拡大に基づく埋め込み手法である.この手法の利点とし ては埋め込み処理による劣化の知覚困難性が挙げられる。ま た，対象領域およびペアの設定によっては埋め込みによる ファイルサイズ増加を抑制できる.そこで本研究ではXuan らの手法を可逆的プライバシー保護技法の復元情報埋め込 み・抽出手法として用いる.

ここでヒストグラムペアに基づく埋め込み・抽出概要に ついて述べる. ある係数值 $x$ は $x \in\{a, b\}$ で表され, $a<b$ かつ $b=a+1$ の関係にあるとする. またヒストグラムに おいてビンの大きさを $h(x)$ と表す。このとき以下の条件に 
当てはまる組がヒストグラムペアである.

(a) if $0 \leqq a, h(a) \neq 0$ and $h(b)=0$

(b) if $b<0, h(a)=0$ and $h(b) \neq 0$

ここで $h(x)$ が 0 ではない係数值は original position, $h(x)$ が 0 である係数值は expansion position と呼ばれる. 条件 (a) では $x=a$ が original position であり, $x=b$ が expansion position である. 条件 (b) では $x=b$ が original position であり, $x=a$ が expansion position である.

ヒストグラムペアの生成と 1 ビットの埋め込み例を以下 に述べる. 各手順で条件 (a) の場合と条件 (b) の場合を併 記した。

i (a) original position である a を決定する

(b) original position である b を決定する

ii (a) $a+1$ 以上のヒストグラム分布を正方向へ 1 拡 大し，ヒストグラムペア $h(a) \neq 0$ and $h(b)=0$ を 作成する

(b) $b-1$ 以下のヒストグラム分布を負方向へ 1 拡 大し，ヒストグラムペア $h(a)=0$ and $h(b) \neq 0$ を 作成する

iii (a)(b) “1”を埋め込む場合は expansion position の $h(x)$ を 1 増加させ, original position の $h(x)$ を 1 減少させる。また, “0”を埋め込む場合はヒスト グラムに変化はない.

抽出処理は original position と expansion position の係数 值, 埋め込みビット数が必要となり, 埋め込み bit 数分だ け逆操作を行う。

\section{3. 提 案手 法}

この章で提案手法の全体的な流れについて述べる．提案 手法は JPEG 圧縮に内包するプライバシー保護処理である. まずカメラで撮影した入力画像中に映り込んだ人物の人体 検出を行いマスク画像を生成する。人体検出手法として, 従 来手法 $[6]$ では処理時間が非常に遅い複雑な処理を施した が，提案手法では，マスク画像の生成には背景差分アルゴ リズム (background mixture models algorithms [11])を 用いる. 次にマスク画像を $8 \times 8$ ブロックに分割し, 半開 示スクランブル処理を施すブロックには “1”，施さないブ ロックには“0”というスクランブリング可否情報を付加す る.このスクランブリング可否情報をスクランブリング情 報と定義する。そしてスクランブリング情報に基づき人物 形状に沿ったプライバシー保護処理を施す。

なお，スクランブル処理を施すブロックをスクランブル ブロック，施さないブロックをアンスクランブルブロック とする.

提案手法のプライバシー保護処理は各 $8 \times 8$ ブロックの $\mathrm{Y}$ 成分の $\mathrm{qDCT}$ 係数 $\mathrm{AC}$ 成分を対象とする. 各 $8 \times 8$ ブロッ ク内の係数は左上ほど低周波成分を表し右下ほど高周波成 分を表す。人間は高周波成分の変化を知覚しにくく低周波 成分の変化を知覚しやすい特徵がある。この特徵を利用し

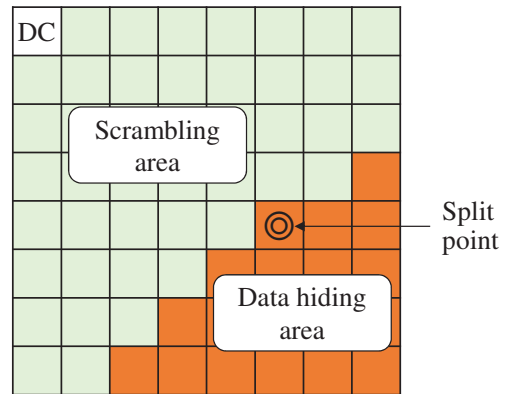

図 3 スクランブリング領域とデータハイディング領域

図 3 のように全ブロックをスクランブリング領域とデータ ハイディング領域に分割する．プライバシー保護表現は人 物領域に対し半開示スクランブル技法により引き起こされ る画質劣化であるため, 劣化を認知しやすいブロック内左 上をスクランブリング領域とする。そして復元情報である スクランブリング情報は可逆的データハイディング技法に より全ブロックに埋め込まれるため，埋め込みによる知覚 的影響の少ないブロック内右下をデータハイディング領域 とする.

全ブロックでの処理を終えた後, 可変長符号化しプライ バシー保護処理された JPEG 画像を出力する。なお入力パ ラメータおよび復号鍵は半開示スクランブル処理に用いる TPSNR と領域分割情報である。

\section{1 スクランブリング情報}

白黒二值マスク画像を $8 \times 8$ ブロックに分割した際にブ ロック内に白のピクセルが閾值 $t \%$ 以上存在する場合 “ 1 ”, 未満の場合は “ 0 ” というスクランブリング情報を付加す る. 人物形状に沿ったプライバシー保護処理を行うため適 切な閾值 $t$ を設定する必要がある。そこでこの閾值 $t$ を $\mathrm{F}$ 值 $(F-$ measure $)$ 測定により決定する. F 值は適合率 (precision：正確性の指標) と再現率 (recall：網羅性の指 標) の総合評価を行う尺度である. 元のマスク画像とスク ランブリング情報を白黒二值マスク画像化した画像 (以後, ブロックマスク画像とする) を比較し, 最も F 值が高くな る閾值 $t$ を求める. ブロックマスク画像は，元のマスク画 像においてブロック内に白のピクセルが閾值 $t \%$ 以上存在 する場合そのブロック内のピクセルを全て白とし，未満の 場合そのブロック内のピクセルを全て黒にすることで生成 される. 適合率, 再現率および $\mathrm{F}$ 值は以下の式 $(2) \sim(4)$ よ り求める.

$$
\begin{array}{r}
\text { precision }=\frac{\text { pixels }_{\text {match }}}{\text { pixel }_{\text {mask }}} \\
\text { recall }=\frac{\text { pixel } s_{\text {match }}}{\text { pixels } \text { blockmask }_{\text {bision } \times \text { recall }}} \\
F-\text { measure }=\frac{2 \times \text { precision }+ \text { recall }}{\text { precision }}
\end{array}
$$

pixels $s_{\text {mask }}$ はマスク画像のピクセル, pixels blockmask $_{\text {b }}$ ブロックマスク画像のピクセル, そして pixel $s_{\text {match }}$ は両 画像の一致ピクセル数を示す. 


\section{2 スクランブリング領域とデータハイディング領域}

プライバシー保護レベル制御のためにスクランブリング 領域では二乗誤差に基づく半開示スクランブル技法 [7] を 用い, 復元情報の埋め込みのためにデータハイディング領 域ではヒストグラムペアを用いた可逆的データハイディン グ技法 $[9,10]$ を用いる.

まずスクランブリング領域内での処理について述べる. この処理はスクランブリング情報が “1”である場合のみ行 う。すなわち対象ブロックはスクランブルブロックである. 以下に各ブロックの処理手順を示す.

（i） データハイディング領域にスクランブリング情報 “1”を埋め込む. 埋め込みによるブロック内発生二 乗誤差 $E^{2}$ を算出する.

(ii ) 式 (1) により設定 TPSNR から必要二乗誤差 $N^{2}$ を求める.

（iii） スクランブリング領域内で可逆的な係数操作を行 い $E^{2}$ を算出し，その值を更新する.

（iv） $E^{2}$ が $N^{2}$ に到達する，もしくはスクランブリング 領域内の対象係数を全て操作するまで手順 iii を繰り 返す.

（v） 次スクランブルブロックヘ繰り越す $N^{2}$ を算出する. 手順 $\mathrm{i}$ は対象ブロック内で二乗誤差に基づくスクランブル 処理 [7] を正確に行うため, データハイディング領域におけ るスクランブリング情報の埋め込みによる発生二乗誤差を 考慮する処理である. 手順 ii で必要二乗誤差 $N^{2}$ を算出す るが，前スクランブルブロックにおいて手順 $\mathrm{v}$ で繰り越し $N^{2}$ が生じていた場合, その分を現スクランブルブロック の $N^{2}$ に加算する. 手順 $\mathrm{v}$ における繰り越し $N^{2}$ は現スク ランブルブロックにおける不足二乗誤差である. なお， ス クランブリング情報が “0” である場合対象ブロックはアン スクランブルブロックであり，スクランブル領域に対する スクランブル処理を行わずデータハイディング領域にスク ランブリング情報 “0”の埋め込みのみ行う.

次にデータハイディング領域内でのスクランブリング情 報の埋め込み処理について述べる. この処理の対象ブロック は全ブロックであり，各データハイディング領域に“1”か “0”の情報 1 ビットが埋め込まれる．2.2 節で述べたように Xuan らの手法 [9] の埋め込みではヒストグラム内で変動す る original positionの $T$ と埋め込み処理を終える original position $S S$ が必要である.ここでデータハイディング領 域内係数の特徵に注目する. 領域内の係数は高周波成分であ り量子化処理により多くの係数が零係数であると考えられ る. $\mathrm{h}(0) \neq 0$ と仮定すると, ヒストグラムペアを original position $=0$, expansion position=1 に固定し埋め込み・抽 出を行うことができる。 スクランブリング情報 “0” の埋め 込みでは $h_{0,1}=[h(0), 0]$ と変化はないが, “1”の埋め込み では $h_{0,1}=[h(0)-1,1]$ と変化する.このヒストグラムの 変化はデータハイディング領域内の最初の零係数が 1 に置 き換わることを意味する. なお, $\mathrm{h}(0)=0$ の場合, 埋め込

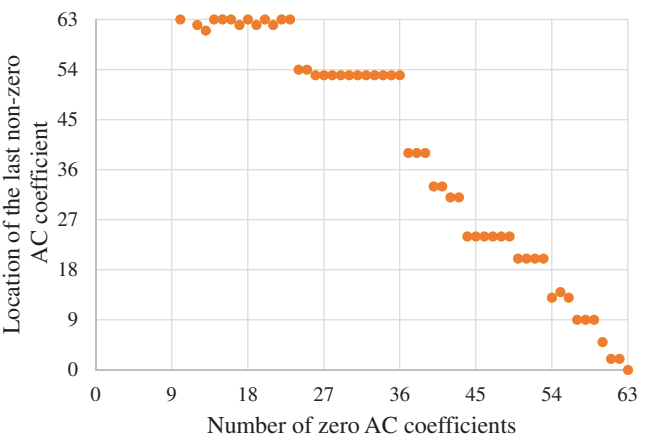

図 4 JPEG Quality = 90 のでのブロック内の零係数の個数 と最後の非零係数の場所の関係図

表 1 JPEG Quality=90 の領域自動分割用テーブル

\begin{tabular}{|c||c|c|}
\hline Type & Number of zero coefficients & Split point \\
\hline 1 & $\sim 36$ & 54 \\
\hline 2 & $37 \sim 39$ & 40 \\
\hline 3 & $40 \sim 43$ & 33 \\
\hline 4 & $44 \sim 49$ & 25 \\
\hline 5 & $50 \sim 53$ & 21 \\
\hline 6 & $54 \sim 56$ & 14 \\
\hline 7 & $57 \sim 59$ & 10 \\
\hline 8 & $60 \sim$ & 3 \\
\hline
\end{tabular}

み処理およびスクランブル処理は行わないこととする.

\section{3 領域分割}

各ブロックをスクランブリング領域とデータハイディン グ領域に分割する領域分割方法について述べる。ここでデー タハイディング領域がブロック内で始まる場所を分割点と 定義する．各ブロックの分割点を手動により決定する場合， データハイディング領域内の零係数を 1 に置き換えるため, 零ランレングスが乱れるため, 設定場所によってはファイ ルサイズ増加を招く要因となる。そのため手動による分割 点の設定は経験的考察が必要となる. 分割点の自動化を行 うために, 20 枚の JPEG 画像を用いて JPEG 画像の各ブ ロック内 $\mathrm{Y}$ 成分 $\mathrm{qDCT}$ 係数における零係数の個数と最後 の非零係数の場所の関係を調査した。 JPEG Quality 90 に設定した結果は図 4 となった。横軸はブロック内の零係 数の個数であり, 縦軸は各零係数の個数において最大頻度 を記録したブロック内の最後の非零係数の場所である．最 後の非零係数の場所はブロック内でのジグザグ走査での番 号を示す。これらの結果から Quality=90 用の領域自動分 割用テーブルを作成した (表 $\mathbf{1}$ ). 表 1 における分割点番号 はジグザグ走査番号である.

このテーブルを利用した処理の流れを以下に示す.

（i） 対象ブロック内の零係数の個数を調べる.

（ii）テーブルより分割点を算出し領域分割を行う. 零 係数の個数が各 Type の上限である場合 Type を 1 あげて分割する (最上位の Type を除く).

（iii） スクランブリング情報に応じて各領域で処理を 行う.

この処理手順は保護処理・解除処理ともに同じである. ス クランブル情報 “1” の埋め込み処理によりブロック内の零 


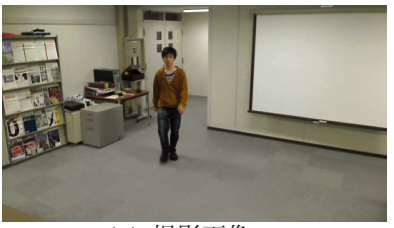

(a) 撮影画像 a

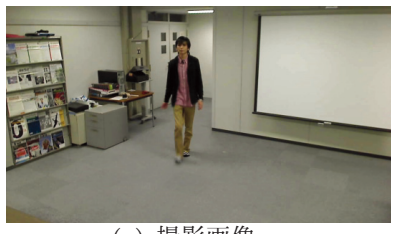

(c) 撮影画像 c

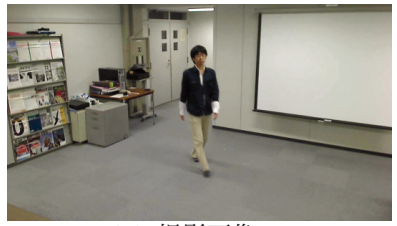

(b) 撮影画像 b

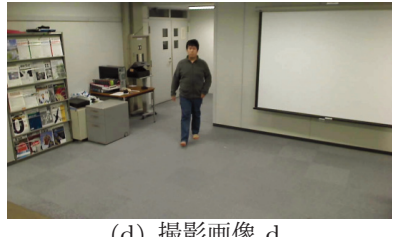

(d) 撮影画像 d
図 5 撮影画像

係数の個数が変化すると解除処理時に誤った領域分割を行 う場合があるため，手順 ii の Type 変更はその対策である. このテーブルを利用する場合, スクランブリング領域内で のスクランブル処理は領域内の零係数の個数を変化させて はならない. なお, 各テーブル情報は復号鍵の一つとする.

\section{4. 実 験}

\section{1 実験概要}

提案手法の有用性を確認するため, 提案手法により生成 した画像・動画像における, スクランブル強度制御実験お よびプライバシー保護レベル実験を行った。保護対象人物 として 4 人用意し, 実際の利用を想定し室内で撮影した, $1280 \times 720$ の画像・動画像を使用した (図 5). それぞれの 画像 ·動画像に保護対象人物として各画像一人ずつ, 人物 領域に対し提案手法によるプライバシー保護処理を行った. スクランブリング領域での処理内容は逆ジグザグ走査順で の符号反転処理と擬似乱数による係数交換処理の 2 種類の 比較を行った。 JPEG 圧縮の Quality は全て 90 とし, 処 理画像の TPSNR は 20, 30dB に設定した. 3.1 節で述べ たスクランブリング情報生成において閾值 $\mathrm{t}$ を $10,20, \cdots, 90$ の 9 段階に設定し， F 值測定を事前に行ったところ，すべて の画像において閾值 $t=50$ のとき $\mathrm{F}$ 值が最大となった。こ の結果から閾值を $\mathrm{t}=50$ に設定した. 動画のフレームレー トは $15 \mathrm{fps}$ とし, 一枚ずっプライバシー保護処理を行った JPEG 画像を連続で格納した Motion-JPEG 形式とする. 主観評価実験は 10 代から 30 代までの 37 名の男女の回答 者に対し，プライバシー保護レベルや画質劣化に関する質 問を行った。

\section{2 処理画像の復元}

プライバシー保護処理画像に対し，復号鍵として TPSNR と領域分割情報を用いて復元処理を行い, 提案手法の可逆 性を確認した。ここでの復元画像はオリジナルイメージを提 案手法と同設定でプライバシー保護処理を行わない JPEG 圧縮した画像とする。撮影画像 b を図 6 , 符号反転処理を 行った画像 b を図 7, 係数交換処理を行った画像 $\mathrm{b}$ を図 8, 復元した画像は図 9 に示す. 通常の JPEG 圧縮画像と比較

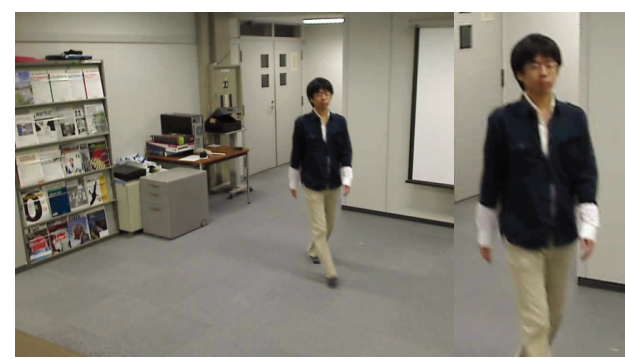

図 6 撮影画像

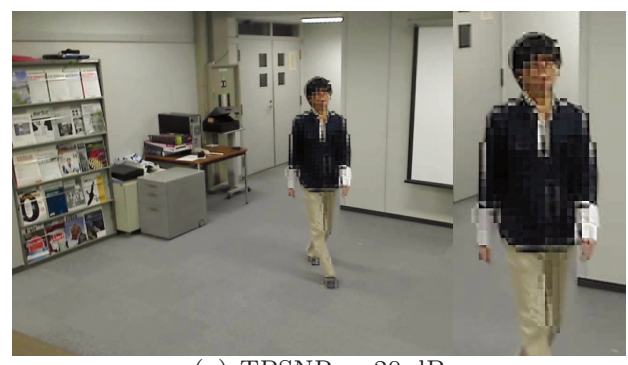

(a) $\mathrm{TPSNR}=20 \mathrm{~dB}$

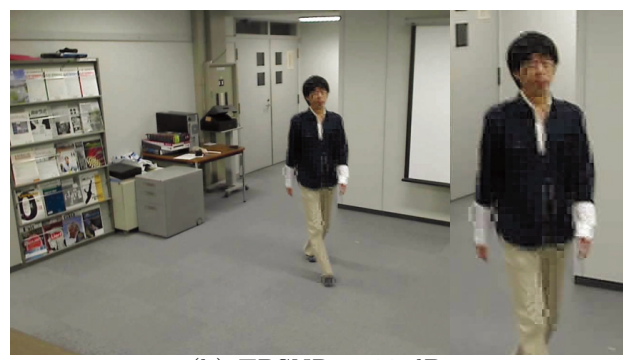

(b) TPSNR $=30 \mathrm{~dB}$

図 7 処理画像 $\mathrm{b}($ 符号反転処理)

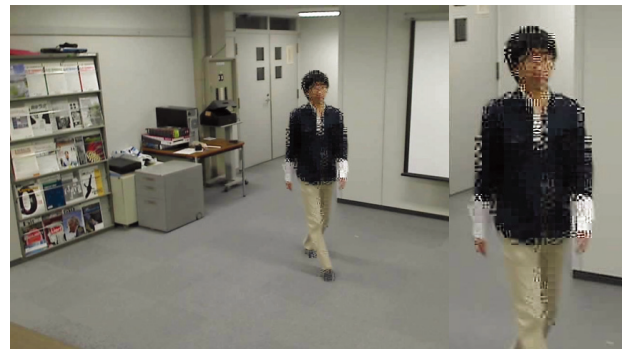

(a) $\mathrm{TPSNR}=20 \mathrm{~dB}$

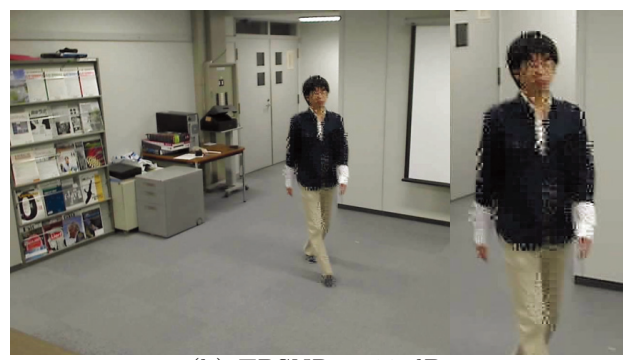

(b) TPSNR $=30 \mathrm{~dB}$

図 8 処理画像 $\mathrm{b}$ (係数交換処理 $)$

し, 復元画像の画素值が誤差なく復元できたことを確認し た。これは本手法では qDCT 係数に対し処理を行うため, 量子化における情報欠損が発生しないためである.

\section{3 スクランブルブロック PSNR 測定}

各 TPSNRにおける本手法での処理が定量的に制御可能 かを実験により確認した。各TPSNRにおけるそれぞれの スクランブル処理と PSNR の結果を表 2,3 に示す. また, 


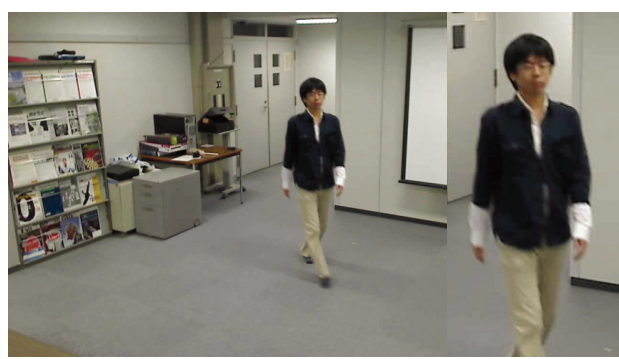

図 9 復元画像

画質の劣化度を絶対範疇尺度法 (ACR: Absolute Category Rating)により主観的な評価を行った。回答者は “非常に 悪い”を評点 1 とし，“非常に良い”を評点 5 とする五段階 で処理画像の評価を行う。処理対象領域における画質劣化 度の主観評価の結果を図 10 に示す。縦軸が評価值の平均 MOS(Mean Opinion Score) である.

測定平均 PSNR 結果について考察する。表 2,3 より, 各画像の平均 PSNR においておおよそ TPSNR に応じた 強度制御を行えたといえる。しかし，TPSNRの低下に伴 い, PSNR との誤差が大きくなっている.これは TPSNR が低いほど必要となる二乗誤差が増加するため, 必要二乗 誤差に到達したスクランブルブロックが減少したことが原 因と考えられる。表 2,3 の各 PSNR 值と図 10 の対応す る TPSNR での MOS 值を比較すると PSNR と主観評価 での劣化度がほぼ一致しており，視覚的にも劣化度を定量 的に調節することができたといえる．測定平均 PSNR 值を 比較すると，係数交換処理が符号反転処理より低い PSNR 值を示していることがわかる。このことから符号反転処理 は同じ測定平均 PSNR ベースで比較した場合，符号反転処 理がより視覚的劣化を感じやすいと考えられる.

\section{4 プライバシー保護レベル実験}

各 TPSNR における本手法での処理により，対象人物の プライバシーが保護されているか主観評価により確認した. 主観実験回答者に対し，以下の二つの質問を行った.

(i) 処理画像の人物を不特定多数から特定可能か.

（ii） 4 人の参考画像から対象人物を 4 択から特定可能か. それぞれの回答をリッカート尺度 [12]により 5 段階で評価 を行った。(i) の結果を図 11, (ii) の結果を図 12 に示す. 縦軸が全体に対する評価人数の割合，横軸が質問に対する 回答である.また, 図 12 の “DN”は“わからない”を示し ている。

本手法のプライバシー保護レベルについて考察する.図 11, 図 12 より, TPSNR $=20 \mathrm{~dB}$ では係数交換処理と符号 反転処理は半分以上の被験者が対象人物を特定不可能だと 答弁したことと，4 人の参考画像から対象人物を特定する 正答率が $40 \%$ 未満であることから，両方の処理はともに充

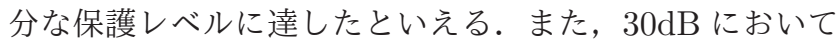
図 12 より，符号反転処理に比べ係数交換処理はよりプラ イバシー保護レベルが強いことがわかる，すなわち，高い TPSNR 時においては符号反転処理に比べ係数交換処理は
表 2 スクランブルブロックの測定平均 PSNR(係数交換処理) $[\mathrm{dB}]$

\begin{tabular}{|c||c|c|c|c|c|}
\hline TPSNR & Image a & Image b & Image c & Image d & Average \\
\hline 20 & 26.34 & 26.78 & 25.39 & 27.81 & 26.58 \\
\hline 30 & 30.81 & 30.68 & 29.49 & 30.97 & 30.49 \\
\hline
\end{tabular}

表 3 スクランブルブロックの測定平均 $\operatorname{PSNR}$ (符号反転処理) [dB]

\begin{tabular}{|c||c|c|c|c|c|}
\hline TPSNR & Image a & Image b & Image c & Image d & Average \\
\hline 20 & 29.75 & 29.50 & 27.42 & 32.40 & 29.77 \\
\hline 30 & 31.07 & 31.51 & 29.29 & 33.51 & 31.35 \\
\hline
\end{tabular}

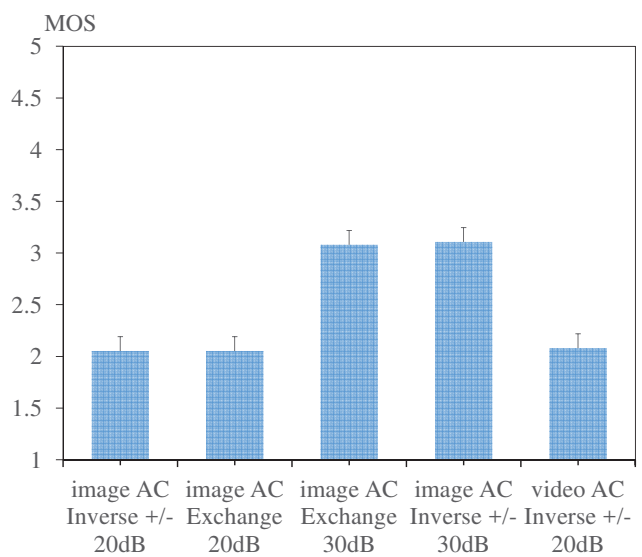

図 10 人物領域における画質劣化度の主観的な評価
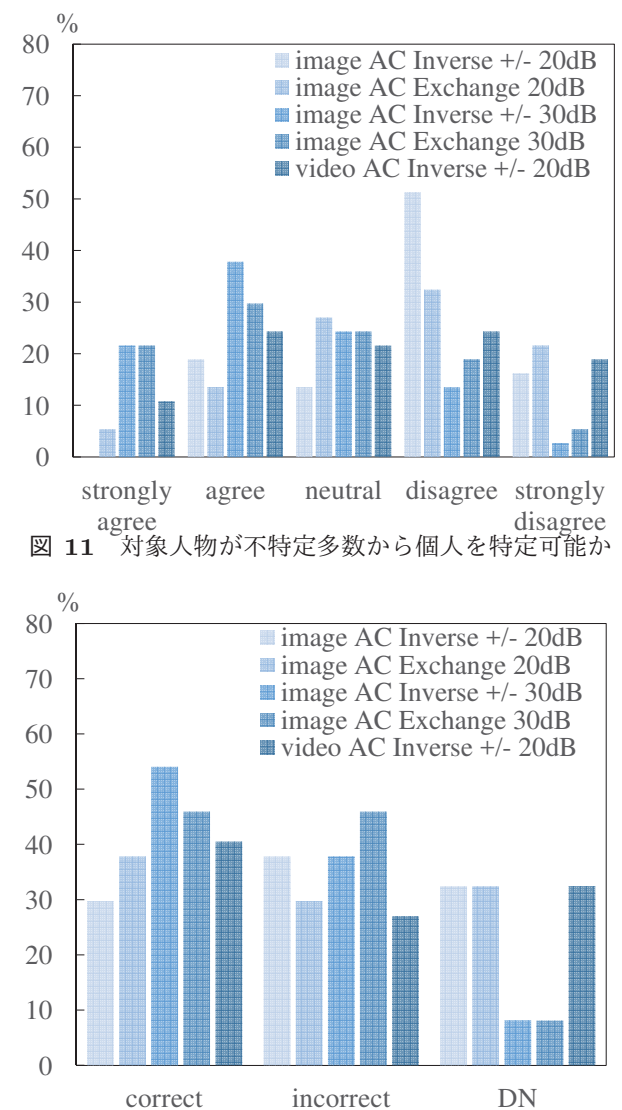

図 124 人の参考画像から対象人物を 4 択から特定可能か

より視覚的な保護レベルが強い特徵があるといえる.

\section{5 動作の検出実験}

動画像において, 処理動画から人物の動作が検出可能か 主観評価により確認した。主観実験回答者に対し，人物の 動作が特定可能かどうかをリッカート尺度により 5 段階で 


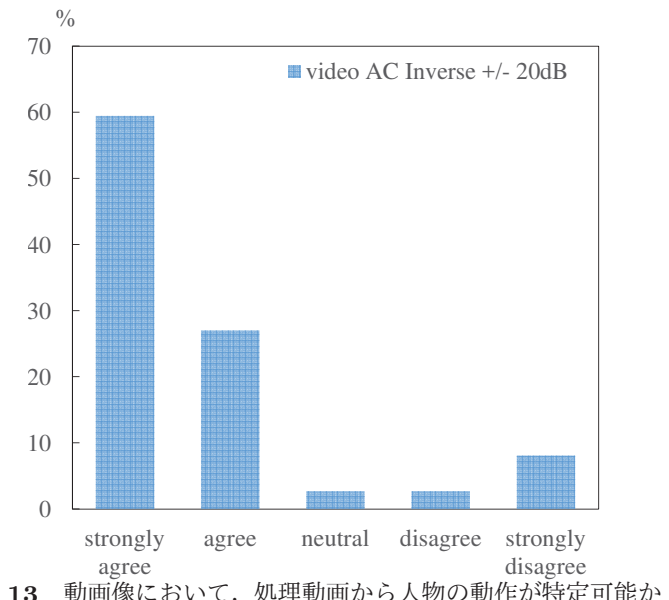

評価を行った。動作の検出実験の結果を図 13 に示す.

動画像における動作の検出について考察する. 図 13 の結 果から， $80 \%$ の人物がどのような動作か検出可能であると 認識していることがわかる．また，動画像の劣化度は同じ 処理を行った静止画の結果と相似しており, 充分な保護し ベルを保ちつつ, 動作の検出が可能であるといえる.

これらの結果から本手法は TPSNR に従ったスクランブ ル強度制御により視覚的に充分な保護レベルの調節を行え たことを確認できた。また本手法によって人物のプライバ シーが充分に保護されているといえるが，TPSNR の設定 值と PSNR との誤差, 人物の映り込み具合に応じてスクラ ンブルブロック内のスクランブル領域に対する処理内容等 を更に検討する必要があると考えられる.

\section{6 処理時間とファイルサイズ増加率の評価実験}

画像もしくは動画像の 1 フレームにおいて，処理の全体 時間, 提案手法の処理時間と JPEG 圧縮の処理時間を計り, 評価実験を行った。使用した処理コンピューターのスペッ クを表 4 に示す．画像一枚あたりの処理時間評価実験の結 果を表 5 に示す。

処理時間評価実験の結果から，一枚の画像における JPEG 圧縮の処理時間が平均 $576 \mathrm{~ms}$ に対し，提案手法の処理時間 が平均 $183 \mathrm{~ms}$ と, JPEG 圧縮の処理時間の三分の一未満に 抑えられたことがわかる。.また, 従来手法 [6] では解像度 が $640 \times 480$ の画像における処理時間が $7000 \mathrm{~ms}$ 以上だっ たのに対し，提案手法では解像度が $1280 \times 720$ の画像に おける処理時間が平均 $183 \mathrm{~ms}$ だったことから，提案手法は 従来手法より処理時間を大幅に短縮できたといえる。なお， 本手法における処理はソフトウェアによるもので，ハード ウェアに実装すれば，さらに大幅な時間短縮が図れるため, 本手法の処理速度は実用に耐えうると考えられる。

提案手法におけるスクランブル処理によるファイルサイ ズ増加率を測り，評価実験を行った。ファイルサイズの増 加率を表 6 に示す.

ファイルサイズ増加率評価実験の結果から，提案手法の 処理はファイルサイズの増加率を $1 \%$ 未満に抑えられるこ とがわかる，そのため，提案手法にはファイルサイズの増
表 4 処理コンピューターのスペック

\begin{tabular}{|c||c|}
\hline OS & Windows 7 Professional 64bit \\
\hline CPU & Intel Core i7-2600K \\
\hline Clock rate & $3.40 \mathrm{GHz}$ \\
\hline
\end{tabular}

表 5 画像一枚あたりの処理時間 $[\mathrm{ms}]$

\begin{tabular}{|c||c|c|c|}
\hline TPSNR, Process & Total & Proposed Process & JPEG Compression \\
\hline 20dB, Inverse & 755 & 182 & 573 \\
\hline 20dB, Exchange & 759 & 183 & 576 \\
\hline 30dB, Inverse & 764 & 186 & 578 \\
\hline 30dB, Exchange & 761 & 182 & 579 \\
\hline
\end{tabular}

表 6 スクランブル処理によるファイルサイズ増加率 [\%]

\begin{tabular}{|c||c|}
\hline TPSNR, Process & Overhead \\
\hline 20dB, Inverse & 0.46 \\
\hline 20dB, Exchange & 0.62 \\
\hline 30dB, Inverse & 0.45 \\
\hline 30dB, Exchange & 0.59 \\
\hline
\end{tabular}

加抑制効果があると考えられる.

\section{5.むすび}

本論文では，目標となる PSNR より算出された二乗誤差 を基準とした半開示スクランブル技法とヒストグラムペア による可逆的データハイディング技法を組み合わせた監視 カメラ画像を対象とした可逆的プライバシー保護手法を提 案した。これまで提案されてきた可逆的プライバシー保護 手法は第三者行為による記録画像の流出に付随したプライ バシー侵害行為を防ぐことはできるが，監視者の見る画像 はプライバシー保護処理が施されていないため，悪意ある 監視者によるプライバシー侵害行為への対策が無い，その ために，監視者の見る監視画像にプライバシー保護レベル を維持しつつ, 動作の検出が可能な保護レベルに調節する 必要がある．そこで提案手法ではこれらの問題を解決する ため, 定量的スクランブル強度制御可能な半開示スクラン ブル技法に注目し，この技法を画像内の人物領域のみに施 すことで監視者が「映り込む人物が誰であるかは分からな いが何をしているか確認できる」プライバシー保護画像の 生成が容易となった。そしてスクランブル強度制御実験お よび主観評価実験を通して, 提案手法は人物領域のみに目 標となるPSNR に応じて充分な保護レベルの調節が可能で あることを確認した。また，充分な保護レベルを保ちつつ， 動作の検出が可能であることも確認した。ささらに，処理時 間とファイルサイズ増加率の評価実験を行い，提案手法は 実用に耐えうることを確認した。

今後の課題としては, 主観評価に近い評価值が算出 できるとされる人間の視覚特性を考慮した指標である

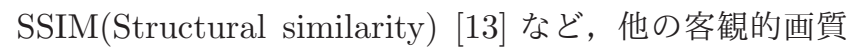
評価指標に基づく半開示スクランブル処理の模索も必要だ と考えられる．また現時点ではJPEG 圧縮画像一枚ずつを 対象とする処理であるが，他の動画コーデック内への提案 手法の適用も課題の一つである. 


\section{〔文献〕}

1）馬場口 登, “視覚的なプライバシー・センシティブ情報とその処理,”シス テム/制御/情報: システム制御情報学会誌, 54, 6, pp. 242-247 (2010)

2) G. Li, Y. Ito, X. Yu, N. Nitta, and N. Babaguchi, "Recoverable Privacy Protection for Video Content Distribution, " EURASIP Journal on Information Security, 2009 (2009)

3) T. Honda, Y. Murakami, Y. Yanagihara, T. Kumaki, and T. Fujino, "Hierarchical image-scrambling method with scramble-level controllability for privacy protection," Proc. 56th IEEE International Midwest Symposium on Circuits and Systems (MWSCAS), pp. 1371-1374 (2013)

4) F. Dufaux and T. Ebrahimi, "Scrambling for video surveillance with privacy, " Proc. IEEE Conference on Computer Vision and Pattern Recognition Workshop 2006 (CVPRW'06), pp. 160-166 (2006)

5）栘谷 冬樹, 新見道治, 野田秀樹, “可逆的情報ハイディングを利用した JPEG 画像のプライバシー保護, ”信学技報, 111, 496, EMM 2011-69, pp. 31-36 (2012)

6）島浦紳吾，姜錫，坂本雄児，“定量的スクランブル強度制御およびファイル サイズ増加抑制可能な可逆プライバシー保護手法”信学技法 EMM201451, pp. 41-46 (2014)

7）島浦紳吾, 原田翔平, 姜錫, 坂本雄児, “定量的劣化度調節可能な DCT 係 数交換による画像半開示スクランブル技法におけるファイルサイズ増加 抑制に関する検討,”信学技報, 113, 135, EMM2013-24, pp. 167-172 (2013)

8) A.Shiozaki, M. Iwata, and A. Ogihara, "Reversible watermarking method for JPEG images," IEICE Trans. Inf \& Syst., E91-D, 7, pp.2068-2071 (2008)

9) G. Xuan, Y.Q. Shi, Z. Ni, P. Chai, X. Cui, and X. Tong, "Reversible data hiding for JPEG images based on histogram pairs, " 4th Inter.Conf., ICIAR'07, LNCS 4633, pp. 715-727 (2007)

10) H. Sakai, M. Kuribayashi, and M. Morii, "Adaptive reversible data hiding for JPEG images," in International Symposium on Information Theory and Its Applications (ISITA), pp. 1-6 (2008)

11) C. Stauffer and W. Grimson, "Adaptive background mixture models for real-time tracking," IEEE Conf. on Computer Vision and Pattern Recognition, 2:2246, (1999)

12) Rensis Likert, "A Technique for the Measurement of Attitudes," Archives of Psychology 140, 55 (1932)

13) Z. Wang, A. C. Bovik, H. R. Sheikh, and E. P. Simoncelli, "Image quality assessment: from error visibility to structural similarity," IEEE Trans. Image Process., 13, 4, pp. 600-612 (2004)

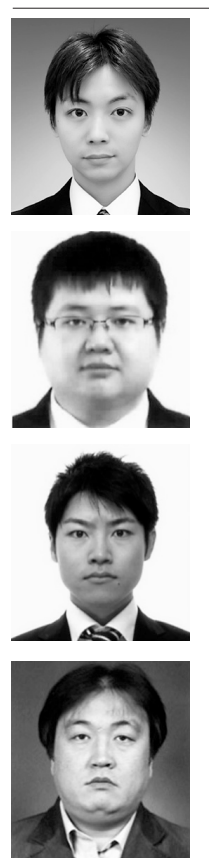

やまもと势德 2014 年, 北海道大学丁学部情報エレ クトロニクス学科卒業. 現在, 同大学大学院情報科学研 究科メディアネットワーク専攻修士課程在学中.コンテ ンツ保護に関する研究に従事。非会員。

李膤覀 2013 年, 中国浙江大学計算機科学技 術学科卒業. 現在, 北海道大学大学院情報科学研究科入 ディアネットワーク専攻博士後期課程在学中.コンテン ツ保護に関する研究に従事. 非会員.

鸷浦紳吾 2013 年, 北海道大学工学部情報エレ クトロニクス学科卒業. 2015 年, 同大学大学院情報科学 研究科メディアネットワーク専攻修士課程卒業. 現在, 日 立製作所.コンテンツ保護に関する研究に従事. 非会員.

姜錫 1994 年, 韓国崇実大学工学部電子計 算学科卒業. 2000 年, 北海道大学大学院工学研究科電子 情報工学専攻博士課程了. 2003 年, 同大学大学院工学研 究科電子情報工学専攻助手，現在，同大学大学院情報科 学研究科助教. 電子透かし, 画像処理, コンテンツ保護 に関する研究に従事. 工博. 非会員.

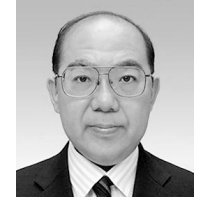

坂热雄児 1983 年, 北海道大学工学部電気工学 科卒業. 1988 年, 同大学大学院博士課程了. 同年, 日立 製作所中央研究所入社. 1990 年, 北海道大学情報工学科 助手。1 994 年, 室蘭工業大学電気工学科助教授。2000 年, 北海道大学工学研究科電子情報工学専攻助教授. 現 在, 同大学大学院情報科学研究科教授. 計算機合成ホ口 グラム，3D 画像処理， CG，ディジタル無線通信に関す る研究に従事. 工博. 正会員. 